\title{
INTERPRETATION OF THE CONCEPT OF FATHER IN SOME ORAL AND WRITTEN SOURCES
}

\section{Ozoda Nizomjon Kizi Anorqulova}

Teacher, Department of "Applied Linguistics, Methods Of Teaching Uzbek Language And Literature", Faculty Of "Philology", Samarkand State University, Uzbekistan

\section{ABSTRACT}

This article provides an overview of the concept, some definitions, and an analysis of the Uzbek paternity term using examples from a variety of sources. The verses of the Quraan, the hadiths, the examples of folklore, and the content that forms the term father in lyrical works are studied as concepts. Each concept is explained with solid examples from the sources. It is also possible to compare the concepts of the term father by comparing them with examples from different sources.

KEYWORDS: - "concept", the term "father", the Qur'an, hadith, oral and written sources, analysis, lyrical sources, folk tales, proverbs.

\section{INTRODUCTION}

In recent years, we have witnessed the frequent use of the term "concept" in the field of linguistics, as well as a lot of scientific research by many scholars, as well as the study of some linguistic units as a concept.

Since the concept of "concept" is an abstract phenomenon, we consider it as a set of meanings that do not exist in a single unit, do not reflect the material form, but are formed by our mind, our thinking. In this regard, M. Rakhmatova states: "As long as the knowledge accumulated during human activity is reflected in his mind, such mental representation is a reflection of national and cultural activity" [6, p. 8]. However, we must not forget that the term "concept" can be equated with such phenomena as "meaning", "concept", but at the same time they are not exactly the same, it is necessary to distinguish between common and different aspects.

In this regard, the linguist Sh. Safarov: Is it possible to use the terms "tushuncha - concept", which is a product of logical activity, and "concept", which are widely used in cognitive linguistics, in the same context? Of course, both of these phenomena are manifested as a unity of thought. The starting point for both is the perception and imagery of the object of reality. " [7]

Indeed, the same word can be expressed in different ways in the minds of different people. For example, "father" can mean "pir - a wise man", "treasure", "head of the family" for one person, "wish" for another, and "stepfather" for others.

\section{THE MAIN FINDINGS AND RESULTS}

In this small scientific article, we also discuss the 
CURRENT RESEARCH JOURNAL OF PHILOLOGICAL SCIENCES 2(7): 20-24,

May 2021 DOI: https://doi.org/10.37547/philological-crjps-02-07-06

ISSN 2767-3758

(C)2021 Master Journals

\section{Crossref do) 8 Google}

Accepted24thJuly, 2021 \& Published 29thJuly, 2021

concepts of the father used in some oral and written sources (verses of the Qur'an, hadiths, the epic "Kuntugmish", folk proverbs, the works of A. Navoi, the work of some lyrical literature); we tried to analyze, albeit briefly.

Since the creation of the universe, there is a term father. We find this term in the verses and stories of the Quraan, which is the heart of our sacred religion, in the Hadith, in all examples of folklore, and in fiction. We will first consider the lexical meaning of the term paternal kinship, and then its conceptual meaning.

The term kinship is a lexical unit used by a father, mainly in Turkish, to refer to a man who has a child or who has adopted someone else's child [9].

Today, the term "father" has such forms as dada, ada, aka, but it is clear from the Quraan and classical and literary works that it is used in the form of ata, ato, padar, padari buzrukvor.

We know that the spread of humanity on earth is also related to the personality of the father. Allah says to the angels, "I want to create a caliph (Adam) on earth". (Surat al-Baqara, 1: 30) Thus, the Lord of the Worlds created Adam. According to the Quraan: Allah teaches Adam all the names... (Surat al-Baqara, 1:31); When Allah commands all the angels, "Worship Adam", they prostrate. Only Iblis refuses, is arrogant, and is one of the disbelievers (Surat al-Baqara, 1: 34).

Adam was tempted by Satan to the tree that God forbade, and his descendants were expelled from Paradise to live as enemies of each other until the day of death, to use it, and to repent.

In addition, the verses of the Quraan repeatedly teach us to respect our parents and to be kind and compassionate to them. After all, parents are the most precious and indebted to human beings after creation!

Remember, we made a covenant with the Children of Israel: "They worship Allah alone, and do good to (father) parents, relatives, orphans, and the poor, be kind to people, perform the prayer perfectly, and pay the obligatory charity". Then you (the Children of Israel) turned away, except for a few of your minority.

(Surat al-Baqara, 83)

0 people! Fear your Lord, Who created you from a single soul, and from it created its mate, and from it created more than two men and women. And fear Allah and the kinsmen who are mentioned in your dealings with one another. Surely Allah is ever watching over you.

(Surat an-Nisa, 1)

There are many such verses in the holy book of our religion. As you read them, you will come to appreciate the value of parenthood, the responsibilities of childhood, and the responsibilities of parenthood.

Let us now turn to the analysis of the conceptual concepts that represent the term father in the hadiths and classical literature.

The father is a great man in the mentality of the Uzbek and fraternal peoples, who is valued as the head of the family, the breadwinner of his children. From time immemorial, values such as the equality of the father with the pir, the opening of the gates of heaven through the parents, and the importance of parental consent have been glorified. This issue is present in all written sources that have come down to us, as well as in the works of A. Navoi, Lutfi, Rabguzi, Yusuf Khos Hajib, Z.M. Babur and many other ancestors. Almost all the works of Alisher Navoi, the great thinker and sultan of the Ghazal dynasty, have special verses about respect for parents and how honorable they are. Everyone has heard the following verses of the author: Sacrifice your head to the spoon, Do the body to the charity. The light that shines day and night is exposed; one understands the moon, one the sun 
CURRENT RESEARCH JOURNAL OF PHILOLOGICAL SCIENCES 2(7): 20-24,

May 2021 DOI: https://doi.org/10.37547/philological-crjps-02-07-06

ISSN 2767-3758

(C)2021 Master Journals

\section{Crossref do) 8 Google}

Accepted24thJuly, 2021 \& Published 29thJuly, 2021

[4].

One of the main themes of Navoi's work is the issue of respect for parents. The above wisdom says that a child should sacrifice his head for his father, dedicate his body to his mother, and know that one is the moon and the other is the sun, just as they illuminate the world.

In Navoi's Mahbub ul-Qulub, the term father appears in various concepts. In one place it is equated with the sun, moon, sun, and rose, in another place it is equated with a pir, and in another place it is equated with a master, a king. The value of the father is highly described in the following masnavi. That is, whoever disobeys his father's command is considered to be playing a game of Pir and Mahdum's deeds: Whoever disobeys his father's command will play with Pir and Mahdum. [3]

Here is another example of a quartet in which the image of the father seems to be inferior to that of the mother. Because it is said that a mother has more rights than a father over her son: A son who cannot replace him, it is possible to have a son without a father. Compare Mary with Christ. That's the decent thing to do, and it should end there. [2]

This issue is also reflected in the hadiths narrated by our beloved Prophet Muhammad Mustafa (peace and blessings of Allaah be upon him):

It is narrated on the authority of Bahz ibn Hakim that he said, "O Messenger of Allah, to whom should I do well?" "To your mother", they said. "Then to whom?", I said. "To your mother", they said. "Then to whom?", I said. "To your mother", they said. "Then to whom?", I said. "To your father and then to your close relatives", he said.

It is clear from the following hadith that the mother's salary is three times higher than the father's. It is permissible to do good to the father after the mother.
The verses of the Quraan, the hadiths, and the written sources of our ancestors serve as sufficient sources to analyze the concept of the father. We will continue such analyzes in more detail in our other studies.

Let's take a look at the interpretation of the concept of father in oral literature. Folklore is a collection of valuable sources that tell about the events of the past, the way of life and mentality of the people. It is a well-known fact that in folk tales, fairy tales, proverbs, proverbs and even riddles there is an inexhaustible treasure. The concept of father, which is the object of our research, is especially common in folklore. As a proof of our point, we will only analyze the concept of the father through the passages used in the epic "Sunrise".

The language of folk epics is an excellent source, which preserves all the beauties, possibilities, purity of our language, the units of dialect. The language of the epic "Kuntugmish", written in the language of Ergash Jumanbulbul's son, which is considered to be more perfect in composition, is also characteristic in this respect. The image of the father in the epic also contains different concepts. Here is just one example of the term quoted from a passage from Doton: My father is Kuntugmish, my father's name is Saint Karakhan, and so I left my people, my parents and my relatives like Nogai and came to your city in search of Holbeka. [5, p. 146]

Also, the fact that the words pushtipanoh and qiblagoh are used in combination with the meaning of the main term served to ensure the stylistic attractiveness and effectiveness of the sentences in the epic: "In the Nogai region, the address is Karakhanshah. if it is a shelter... ". Or, "... When I grow old, my father is from my qibla, my caring father. I lost my care... [5, p. 203]

Through the passage above, we see that it is described at the level of FATHER-CARING, FATHER-PUSHTIPANOH, and FATHER- 
CURRENT RESEARCH JOURNAL OF PHILOLOGICAL SCIENCES 2(7): 20-24,

May 2021 DOI: https://doi.org/10.37547/philological-crjps-02-07-06

ISSN 2767-3758

(C)2021 Master Journals

\section{Crossref do) 8 Google}

Accepted24thJuly, 2021 \& Published 29thJuly, 2021

QIBLAGOH. Which father does not really fit these descriptions? Who doesn't consider their father to be a caring, qibla-oriented person?

There are also many references to the term in proverbs, which are another beautiful example of folklore. In the proverbs of folk wisdom, the word father, we find different forms of the term father kinship. Uzbek folk proverbs more clearly and comprehensively describe the issues of the father's honor, dignity, place and dignity than other sources. Articles about parents are the most popular. This is because the Uzbek people have always been raised by the prayers of their parents, and the consent of the father is equated with the consent of Allah. Human qualities and deeds, such as not even climbing to the roof of the house where the father was staying, not walking one step ahead of them, not doubting his words, not looking straight into his eyes, not speaking, are very beautiful, melodic and given impressively.

In folklore, the father represents many concepts, such as garden, gardener, treasure, state, selfsacrifice. Let's look at some of them:

- "Parents are a garden, one is a flower, one is a gardener".

In this article, the family is compared to a garden, in which the relationship between father and child is equated with the situation between a flower and a gardener. That is, the more skillfully a gardener treats, loves, and nurtures a flower, the more beautiful the flower will be, the more fragrant it will be, and the more pleasing it will be to others. A child who is brought up by a loving father will surely grow up to be a person who will be useful and grateful to the people in the future. Because, "The perfection of a child is the pride of a father". In our analysis, gardening is compared to a father, but in time, this task may be passed on to the child. Because when a father grows old, he becomes a flower in the garden for his child. That is, he needs care, love, and attention. A child who devotes himself to his father's generosity, takes care of him and receives his blessings will always be honored and respected among the people. Because, "You see in your child what you did to your father".

\section{- "The fat of the shoulder is the inheritance of the father, and the fat of the father is the inheritance of the son"}

The Uzbek people are a very wise and intelligent people, who have created such proverbs in two sentences, which can reflect the difficulties of a single father in raising a child. First of all, the word "fat" in the article has several meanings. The first meaning is a purulent wound caused by the crushing of a heavy load on the skin of an animal such as a horse, donkey, or camel. Wound is used in the sense of a wound, and in another sense in the sense of a very dirty, filthy condition of clothing [8, p. 138].

When there are so many, heavy and time consuming, family worries, child rearing, household chores, duties and so on are the responsibilities of a father. The resulting rainfall is as strong as that of any large animal. And children need to learn, appreciate, and, if necessary, inherit the qualities of their fathers. The reason is that "a child is the strength of the waist".

So, in every example of folklore, we find colorful images of the image of the father. We will discuss them in more detail in our future work.

\section{Conclusion}

In conclusion, there are enough sources in Uzbek to analyze the concept of fatherhood. You have seen it above. There are many places for this term in all oral and written examples of Uzbek literature. One of our current responsibilities is to analyze them, to discover new aspects, to conceptually reflect the mental concepts of this term that are reflected in our thinking. 
CURRENT RESEARCH JOURNAL OF PHILOLOGICAL SCIENCES 2(7): 20-24,

May 2021 DOI: https://doi.org/10.37547/philological-crjps-02-07-06

ISSN 2767-3758

(C)2021 Master Journals

Crossief do) 88 Google

Accepted24thJuly, 2021 \& Published 29thJuly, 2021

\section{REFERENCES}

1. Abu Abdullah Muhammad ibn Ismail alBukhari. Al-Jami 'as-Sahih (Vol. 1). Translated from Arabic by Zakirjon Ismail. General edition of encyclopedias, - Tashkent: 1991. - p. 403.

2. Alisher Navoi. Badoe Ul-Wasat. - p. 381. (Electronic version)

3. Alisher Navoi. Mahbub Ul-Qulub. - p. 89. (Electronic version)

4. Alisher Navoi. Hayrat Ul-Abror. - p. 280. (Electronic version)

5. Kuntugmish. Nightingale ceremonies. Volumes 5. Vol 1. - Tashkent: Science, 1971. - p. 20.

6. Raxmatova M.M. (2019) Linguistic features of the concept of "beauty" in English, Uzbek and Tajik national culture. Author's abstract of the dissertation of Doctor of Philosophy (PhD) in philological sciences. - Bukhara.

7. Safarov Sh. (2006) Cognitive linguistics. Jizzakh: Sangzor.- p. 84.

8. Annotated Dictionary of the Uzbek Language, Volumes 5. Vol 4-5. - Tashkent: "NUuZ", 2008.

9. Mamatov A.E. (2012) What is the essence of a cognitive approach to language? Actual problems of Uzbek linguistics: materials of scientific-practical conference.-Andijan: - p. 212.

10. Dictionary of Navoi works. - Tashkent: Gafur Gulom Publishing House of Literature and Art, 1972. 